\title{
Applying Standard Competency Assessment in Vocational Teaching Practices
}

\author{
Mimi Mohaffyza Mohamad ${ }^{1}$, Nabilah Abu Bakar ${ }^{1}$, Nor Lisa Sulaiman ${ }^{1}$, Kahirol Mohd Salleh ${ }^{1} \&$ Lai Che Sern ${ }^{1}$ \\ ${ }^{1}$ Faculty of Technical and Vocational Education, Universiti Tun Hussein Onn Malaysia, Malaysia \\ Correspondence: Mimi Mohaffyza Mohamad Faculty of Technical and Vocational Education University Tun \\ Hussein Onn Malaysia, 86400 Batu Pahat, Johor, Malaysia. Tel: 60-7-456-4118. E-mail: mimi@uthm.edu.my
}

\author{
Received: May 17, 2015 Accepted: July 13, 2015 Online Published: August 18, 2015 \\ doi:10.5539/ass.v11n24p216 URL: http://dx.doi.org/10.5539/ass.v11n24p216
}

\begin{abstract}
Teaching in vocational education is focused on knowledge and skills. Psychomotor is an aspect that emphasized in teaching competency in vocational education. Teaching based on psychomotor is a way to provide students with the hands on skills. Teachers are the main character in the teaching session. Therefore, this paper explained the differences among teachers in teaching based Standard Competency Assessment with their expertise in particular field. Research used survey design involved 301 teachers from Vocational Colleges specifically teaching practical task in Technology Courses. The focused elements are experienced and qualification of expertise based on recognition by Malaysia Skill Certification. Result showed that there are differences in the application of the teaching methods between experienced and inexperienced instructors teaching at the workshop from the teaching and evaluation aspects. The skills certificates ownership by the instructors shows differences in the aspects of teaching methods compared to the teaching implementation. In summary, teachers or instructors who teaching in vocational courses need the basic requirement especially skills recognition to fulfill competency assessment.
\end{abstract}

Keywords: teaching practices, competency standard assessment, psychomotor

\section{Introduction}

Competency Standard Assessment (CSA) System conducted in vocational colleges started in 2012 to measure the performance of individual's achievement at the end of the teaching and learning processes. The certificate level for CSA in vocational colleges outlines $70 \%$ of school-based assessment and the remaining $30 \%$ are central-based, whereas for the diploma level, it consists of $80 \%$ school-based assessment and $20 \%$ are central-based. The Average Grades for the vocational stream before modular assessment was introduced in 2007, 2008 and 2009 were 5.66 and 5.49 and 5.11 respectively. Meanwhile, the Average Grades after the modular assessment was introduced in 2010 and 2011 were 4.38 and 4.45 respectively. There is a reduction of the values of Average Grade from 2007-2012 for vocational examinations, in which the latest achievements are better than the past achievements before modular assessment was introduced. Lower value of Average Grade means better performance of the examination results (Ministry of Education, 2011)

Tan (2010) claimed one of the success factors of School-based Assessment is the instructors' method of structuring the teaching and learning activities in the classroom from the aspects of planning, implementation and evaluation. Robert (2008) also stated that in his study, most academic assessment cases involved a high risk of irresponsibility. Most evaluators focused more on students' good achievement and ignored the teaching planning, implementation and evaluation. This is because students only need to obtain a minimum score of 10 in the central examination score and 30\% competency of the entire module to pass in the Malaysian Certificate of Education (Ministry of Education, 2009).The situation can be seen when the passing percentage of vocational stream increased significantly in 2009, 2010 and 2011, in which the School-based Assessment Module was implemented in these years.

Mahajan (1999) mentioned that the current paradigm in engineering education was built on the structure of the practical teaching requirements in the workshop. Instructors in this field must have not only the technical and vocational skills, but they also need to have teaching skills, as well as mastery of practical skills in ensuring that the information disseminated to the students is accurate and correct. Explanations given by the instructors, professional development and classroom practices bring about the effectiveness against certain practices, in 
which it may be positive or negative depending on their impact on the students' final achievements (Harold, 2001).Educators need to be an expert in an education field before starting their teaching session in the classroom. Fionn (1998) in his study stated that most modular-based teaching and learning create incompatibility between the technique and the teaching content and the students' mastery in teaching, especially the skills.

According to Pinsent (2008), the effectiveness of learning depends on the teaching content and the delivery methods used by the educators. A study conducted by Johari et al. (2009) involving 928 teachers in 22 schools in four districts in Sabah found that the experienced teachers who have been teaching for more than seven years have a greater ability in the teaching aspect compared to the teachers with less than seven years teaching experience. O'Connor et al. (2004) stated that experienced teachers are able to make a better association between the new materials learned with the students' existing knowledge from previous learning, besides encouraging more open and flexible discussions between the teachers and students.

Novice instructors are less confident when dealing with teaching and learning (T\&L) in the classrooms especially when the teaching is in the practical form or skills teaching. Novice instructors were found to have many ideas that would be implemented but in reality, their T\&L were found to be less confident in disseminating or implementing the designed ideas (Guney, 2012, Coulter, 1987; Cruickshank, 1990). According to Darling-Hammond (2000), on average, the instructors who had served less than three years are less effective in the selection of teaching method aspect. However, their quality of service increases continuously until five years and then stabilizes. New instructors are more concerned with work reputation, as well as social relationships between school organizations compared to students' academic achievement. They strive to develop unique and new P\&P methods in attracting students' attentions than enhancing their own knowledge and skills in greater depth in the subject matter that they are teaching (Guney, 2012; Artiles et al., 1994; Housner \& Griffey, 1985; Szpiczka, 1990). The accountability as a teacher is to have certificates of specialization in certain fields, especially in the matters pertaining skills associated with the flow of his/her teaching duties (Kusnawati, 2009).

\section{Research Objectives}

In detail, the research objectives are to:

(i) Identifying the differences between the most dominant CSA teaching method practiced by the experienced and are inexperienced instructors teaching at workshops.

Identifying the differences between the most dominant CSA teaching method practiced by the certified instructors who with and without skills certificates.

\section{Competency Standard Assessment (CSA)}

The main component of implementation assessment in vocational college was a school assessment, centralized assessment, examination center, physical activity assessment, sports and co-curriculum and psychometric assessment. The components focused in order to produce skilled workers in terms of reliability, entrepreneurial, and technical skills (Malaysian Examination Board, 2013).Assessment conducted by instructors of the subjects after the teaching and learning processes. School-based assessment was interpreted evidence process and product for particular competency evidence. The main objective of CSA is to produce graduates of education and vocational training with a workforce skilled, self-confident, knowledgeable, fulfill skilled and accredited standards in industry and accepted by domestic and foreign institution of higher institution (Malaysian Examinations Board, 2013). Scoring competencies for specific module of assessment will be reported in Malaysian Certificate of Vocational (SVM) and Malaysian Skills Certificates (SKM). Centralized assessment conducted in writing that interpret knowledge and evidence of knowledge that handled as same as another Malaysian certificate of education subjects. Table 1 and Figure 1 showed the certification and accreditation of vocational colleges and the percentage requirement in the assessment of vocational colleges.

Table1. Form of percent requirement in assessment of vocational college

\begin{tabular}{cccc}
\hline Level & Module & School-Based Assessment & Centralized Assessment \\
\hline \multirow{2}{*}{ Certificate } & Academic Module & 30 Percent & 70 Percent \\
& Vocational Module & 70 Percent & 30 Percent \\
\multirow{2}{*}{ Diploma } & Academic Module & 20 Percent & 80 Percent \\
& Vocational Module & 80 Percent & 20 Percent \\
\hline
\end{tabular}




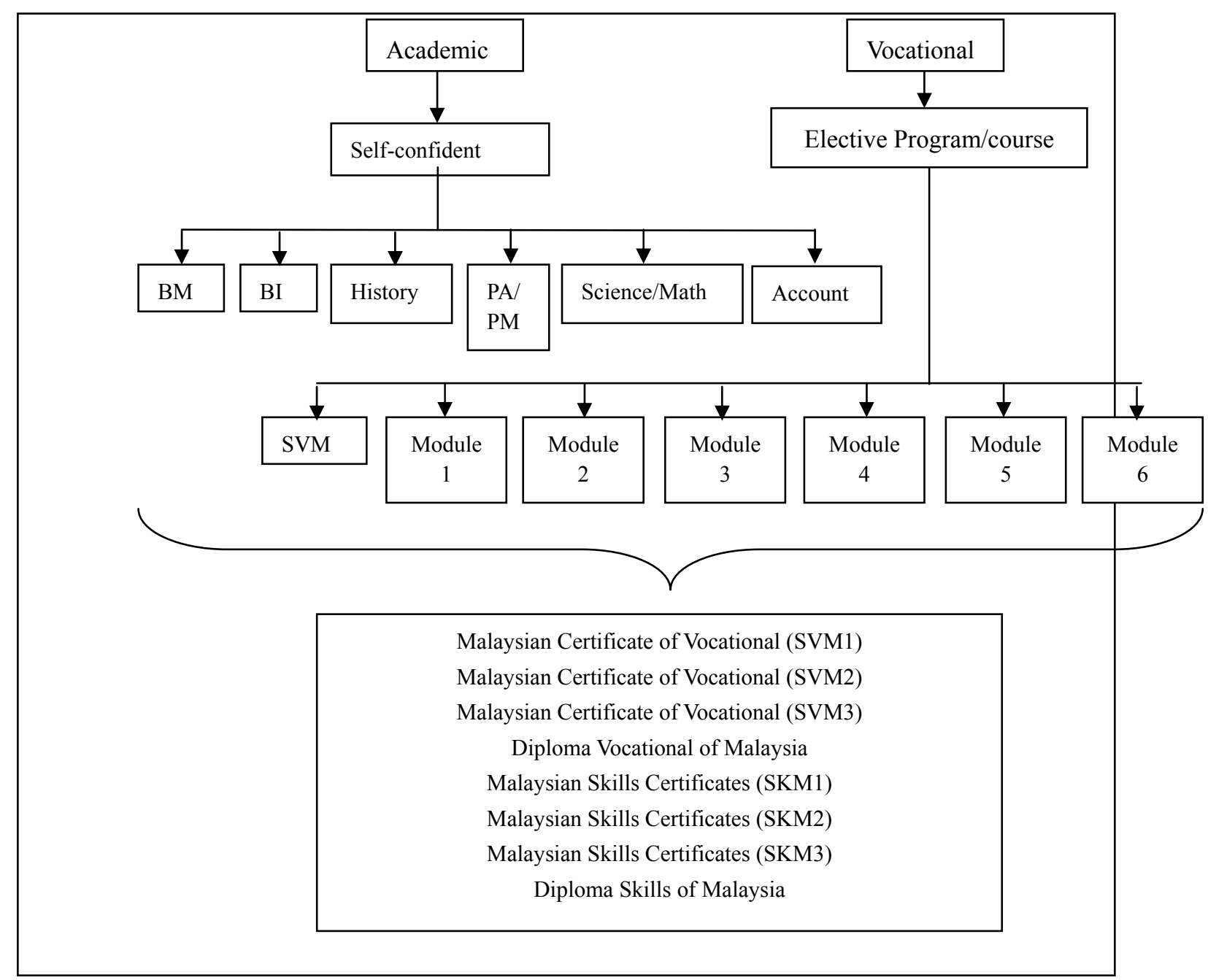

Figure 1. Certification and accreditation of vocational college

\subsection{Teaching Method}

Teaching is an activity that requires of techniques or skills to teach effectively and meaningful. Therefore, instructors need to have expertise, knowledgable, and teaching skills in their study field (Gloria, 2006). Ingersol (2011) and Greenwald et al. (1996) says that the teachers that mastery in their teaching field is an important factor to determine the qualities of the teaching. In teaching and learning field, there are there three process included that have shown as figure below.

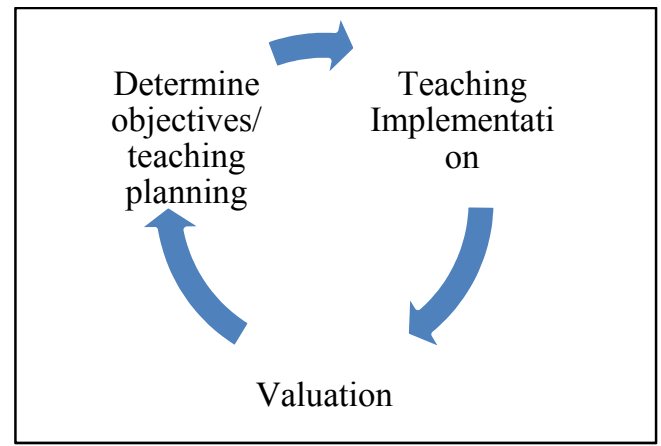

Figure 2. Teaching and learning process (Lorin et al., 2001) 


\section{Methodology}

This study applied a survey research design and using questionnaires to obtain answers to the research questions and testing the hypotheses. The questionnaire is in the quantitative research form to obtain the findings to answer objectives 1 and 2. It is divided into two parts, Part I and Part II. Part I is the demographics of the respondents, whereas Part II is the Practical Teaching Method. Part II is divided into three parts; Teaching Planning, Implementation and Evaluation based on Mok (2000), Tan (2010) and Huitt (2003) . The scale is $1=$ strongly disagree, $2=$ disagree, $3=$ not sure, $4=$ agree, and $5=$ strongly agree. Based on these responses, the application level was measured based on the interpretations of mean score schedule (score range 1.00 to $1.50=$ very low, 1.51 to $2.49=$ low, 2.50 to $3.49=$ moderate, 3.50 to $4.49=$ high and 4.50 to $5.00=$ very high).Further, the differences in the application of the teaching methods based on the instructors' demography were determined. As a whole, the population for the study conducted consisted of the instructors in vocational colleges, where the sample for the study was the vocational instructors only in the workshop. The respondents' selection technique used by the researcher in distributing the questionnaires was based on the simple random sampling method. Random samplings would occur easily where every sample with similar characteristics will have the probability to be selected as a respondent (Louis, 2011). The advantage of simple random sampling is if the sample is large, then the sample will represent the population (Idris, 2010).The number of vocational instructors in Malaysia is 1328 (Ministry of Education, 2014).However, the sample size of the study was determined by referring to Krejcie and Morgan's table (1970), which is a total of 301 workshop vocational instructors. The data obtained to answer the questions from the distribution of questionnaires to the respondents were analyzed. Inferential statistics was used to generalize the results obtained from the research sample. To answer the research hypotheses, the researcher used an analysis of the differences, namely MANOVA test.

\section{Results}

Demographic aspects including the teaching experience in the workshops and ownership of the skills certificates among the vocational college instructors were analyzed descriptively. The differences between instructors' demographic aspects of the CSA teaching method practiced by the instructors were analyzed simultaneously. MANOVA test was used to test the two hypotheses. To conduct MANOVA test, the researcher conducted a test to determine the homogeneity of variance-covariance by using Box's M test. This test is important to determine whether the variance-covariance among the dependent variables is similar across all the independent variables. This is an important prerequisite for MANOVA test. The test assumes that the variance-covariance among the dependent variables is similar across all the independent variables. In this case, if the significance level is greater than 0.01, then MANOVA test is valid to be used in this study (Tabachnick \& Fidell, 1996).

The table below shows the results of Box's M test for the dependent variables of CSA teaching methods for the independent variables of experienced and inexperienced instructors at the workshops. The analysis results for the teaching implementation is $F(1,297.000)=0.03$, and the evaluation of teaching is $F(1,297.000)=0.03$. The significance level is $\mathrm{p}<0.05$ and Ho is rejected for this question because the significant value for the teaching implementation and evaluation aspects is less than 0.05 .

Table 2. Box's M test results for teaching experience by the instructors

\begin{tabular}{cc}
\hline Box's $M$ & 9.03 \\
$\mathrm{~F}$ & 1.49 \\
df1 & 6 \\
df2 & 360399.38 \\
Sig. & 0.18 \\
\hline
\end{tabular}

The Box's M test results for the dependent variables of CSA teaching methods for the independent variables of the instructors with and without skills certificates are shown in the table below. The results analysis for the teaching implementation is $F(1,297.000)=0.050$. The significance level is $p<0.05$ and Ho is rejected because the significant value of the teaching implementation is less than 0.05 .

In the MANOVA analysis, the Pillai's Trace statistical test was used because the number of samples among the instructors with and without skills certificates is different. This matter is supported by Tabachnick and Fidell (1996) where the Pillai's Trace test is suitable if the number of samples is small in size, the number of samples is different or does not meet the prerequisites. Table 4 shows the analysis of the data obtained from the MANOVA 
test results to identify the differences between the teaching methods practiced by the experienced and inexperienced instructors at the workshops. The data shows a significant different between the CSA teaching methods practiced by the experienced instructors of more than 5 years experience and those with less than 5 years experience in the workshop from the aspects of teaching implementation and evaluation. This can be clearly seen when the analysis for the teaching implementation is $\mathrm{F}(1,297.000)=0.03$, and the evaluation of teaching is $F(1,297.000)=0.03$. The significance level is $\mathrm{p}<0.05$ and Ho is rejected for this question because the significant value of the teaching implementation and evaluation aspects is less than 0.05 .

Table 3. Box's M test results for the ownership of the skills certificates aspect

\begin{tabular}{cc}
\hline Box's $M$ & 2.84 \\
F & 0.47 \\
df1 & 6 \\
df2 & 398499.49 \\
Sig. & 0.83 \\
\hline
\end{tabular}

Table 4. Test of between-subjects effect for teaching experience by the instructor

\begin{tabular}{lcccccc}
\hline & Dependent variable & Sum of square & df & Average sum of square & F & Sig. \\
\hline Correction Model & Planning & 0.05 & 1 & 0.06 & 0.06 & 0.81 \\
& Implementation & 2.66 & 1 & 2.66 & 4.81 & 0.03 \\
& Evaluation & 5.83 & 1 & 5.83 & 4.54 & 0.03 \\
& Planning & 3892.34 & 1 & 3892.34 & 4420.67 & 0.00 \\
Intersection & Implementation & 3470.32 & 1 & 3470.32 & 6285.32 & 0.00 \\
& Evaluation & 3381.60 & 1 & 3381.60 & 2636.32 & 0.00 \\
Experience & Planning & 0.05 & 1 & 0.05 & 0.06 & 0.81 \\
& Implementation & 2.66 & 1 & 2.66 & 4.81 & 0.03 \\
& Evaluation & 5.83 & 1 & 5.83 & 4.54 & 0.03 \\
\hline
\end{tabular}
a. $\mathrm{R}^{2}=0.00$ (determine $\left.\mathrm{R}^{2}=-0.003\right)$
b. $\mathrm{R}^{2}=0.016$ (determine $\mathrm{R}^{2}=0.013$ )
c. $\quad \mathrm{R}^{2}=0.015$ (determine $\mathrm{R}^{2}=0.012$ )

Table 5. Test of between-subjects effect for the Malaysia skills certificates

\begin{tabular}{lcccccc}
\hline & Dependent variables & Sum of square & df & Average sum of square & F & Sig. \\
\hline Correction Model & Planning & 0.06 & 1 & 0.06 & 0.07 & 0.79 \\
& Implementation & 2.20 & 1 & 2.20 & 3.97 & 0.05 \\
& Evaluation & 0.93 & 1 & 0.93 & 0.72 & 0.40 \\
Intersection & Planning & 3946.23 & 1 & 3946.23 & 4482.04 & 0.00 \\
& Implementation & 3527.68 & 1 & 3527.68 & 6371.51 & 0.00 \\
& Evaluation & 3475.28 & 1 & 3475.28 & 2675.21 & 0.00 \\
Skill Certificate Ownership & Planning & 0.06 & 1 & 0.06 & 0.07 & 0.79 \\
& Implementation & 2.20 & 1 & 2.20 & 3.97 & 0.05 \\
& Evaluation & 0.93 & 1 & 0.93 & 0.72 & 0.39 \\
& Evaluation & 389.36 & 300 & & & \\
\hline
\end{tabular}
a. $\quad \mathrm{R}^{2}=0.00$ (determine $\mathrm{R}^{2}=-0.003$ )
b. $\mathrm{R}^{2}=0.013$ (determine $\mathrm{R}^{2}=0.010$ )
c. $\quad \mathrm{R}^{2}=0.002$ (determine $\mathrm{R}^{2}={ }^{-} 0.001$ ) 
The table below shows the analysis of the data obtained from the MANOVA test results to identify the differences between CAS teaching methods practiced by the instructors with and without skills certificates. The data shows a significant difference between the CAS teaching methods practiced by the instructors. Ownership of the skills certificates by the instructors shows the difference from teaching methods, where the argument is proved for the teaching implementation aspects, where $\mathrm{F}(1,297,000)=0.05$. The $\mathrm{R}^{2}$ value by referring to Table 5 shows that the ownership of skills certificates by the instructors contributed 0.013 or $1.3 \%$ difference in the dependent variables for the teaching implementation aspect.

\section{Discussions and Conclusions}

In general, the researcher found that there are differences in the application of the teaching methods between experienced and inexperienced instructors teaching at the workshop from the teaching and evaluation aspects. The skills certificates ownership by the instructors shows differences in the aspects of teaching methods compared to the teaching implementation. Johari et al. (2009) in his study found that there are differences in the efficacy between experienced and inexperienced teachers teaching at the workshop. Experienced and inexperienced teachers did not show differences in terms of confidence and the selection of teaching methods that include the aspects of teaching planning, implementation and evaluation. Study conducted by Guney (2012) indicate differences in the teaching aspect, in which experienced teachers gave more emphasis on the implementation of the teaching elements than novice teachers. There was no difference in the teaching preparation and evaluation aspects $\mathrm{d}$ between novice and non-novice teachers.

Study also conclude the analysis are consistent with the results of the studies conducted by Alex and Waynne (2012), Guney (2012) and Johari et al. (2009) in the teaching implementation aspect, where there is a difference in the teaching planning among experienced and inexperienced instructors. The teaching preparation aspect did not show any difference between experienced and inexperienced instructors, and this is consistent with the findings of studies conducted by Alex and Waynne (2012), Guney (2012) and Johari et al. (2009). In the aspect of teaching evaluation application, the researcher found that there are differences between experienced and inexperienced instructors. This situation is in line with the findings by Johari et al. (2009) and Alex and Waynne (2012). However, the finding is contrary to the results of the study conducted by Guney (2012). The results carry out by Teresa (1999) showed that instructors who have the skills certificates produce effective teaching methods than those who do not have the certificates. Instructors with skills certificates used more demonstrations methods and fully involved the students' movement activities compared to the instructors without the certificates. The instructors with skills certificates emphasized on the teaching implementation aspect. For the planning aspect, the instructors either with or without skills certificatesor give less emphasis due to lack of time and busy in solving other matters in the education institutions.

Gloria (2006) reported the instructors with the certificate of mastery of a field have different teaching approach than those who do not have the certificate. Each planning, implementation and evaluation of the teaching is focused on students' final achievement. These instructors understand better the different needs of each student compared to the instructors who do not have the certificate or license, whereby they only depend on the criteria suggested by the administration without making changes or diversifications. Certified instructors are more likely to diversify each teaching method, either traditional or modern, to enhance students' understanding and progress. Results found that there are differences in the application of the teaching aspects among teachers with and without skills certificates, whereas there is no difference in the teaching planning and evaluation. This is consistent with the study conducted by Teresa (1999). However, the planning and evaluation aspects of teaching are not in line with the findings of the study conducted by Gloria (2006). This is because the researcher's study leads to the skills certificates ownership among the instructors at the workshop, where the study findings by Gloria (2006) are more inclined towards the ownership of certificate or license among teachers who are teaching the students with special needs in the United States.

In conclusion, this study shows that there are differences between the demographic aspects of the instructors with the CSA teaching methods practiced by the instructors. The review was carried out to look at the implementation of teaching method based in vocasional college based on CSA. Objective study and the research question has been answered properly. The results of this study are expected to help other teachers, instructors, university students, technical institutions, investigators, and resercher himself.

\section{Acknowledgements}

The author would like to acknowledge University Tun Hussein Onn Malaysia and Ministry of Higher Education for providing the grant RAGS /R042 


\section{References}

Artiles, A. J., Mostert, M. P., \& Tankersley, M. (1994). Assessing The Link Between Teacher Cognitions, Teachers Behaviours and Pupil responsesto Lessons. Teaching and Teacher education, 10(5), 465-481.

Coulter, F. (1987).Affective Characteristics of student teachers.dlm. In M. J. Dunken (Ed.), International Encylclopedia of Teaching and Teacher education (pp. 589-597). Oxford: Pergamon Press.

Cruickshank, D. (1990). Research That Inform Teachers and Teacher Educators. Bloomington, IN: Phi Delta Kappa.

Darling-Hammond, L. (2000).Teacher Quality and Student Achievement. Educational Policy Analysis Archives, $8(1)$.

Fionn, R. (1998). Curriculum Design for A BTEC HND In Interactive Multimedia. Post Graduate Certificate

Gloria, F. S. (2006). The Impact of Teacher Licensure on Student Achievement in Reading And Mathematics As Measured By Proficiency Rates On NcEog Test. East Carolina University: Tesis PHD.

Greenwald, R., Hedges, L., \& Laine, R. (1996). The effect of school resources on student achievement.Review of Educational Research, (66), 361-396.

Guney, H. (2012). Enriching a Preservice Teacher's Classroom Experiences Through Cycles Of Teaching And Reflection. Çanakkale Onsekiz Mart University: Turki.

Harold, W. (2001). Teacher Classroom Practices and Student Performance: How School Can Make A Difference. New Jersey: Educational Testing Service Statistic and Research Division Princeton.

Housner, L., \& Griffey, D. (1985). Teacher Cognition. Research Quarterly for exercise and Sports, 56, 45-53.

Huitt, W. (2003). The psycomotor domain. Educational psycology Interactive. Valdosta GA: Valdosta State University.

Idris, N. (2010). PenyelidikanDalamPendidikan. Malaysia: McGraw-Hill.

Ingersoll, R. M., \& Strong, M. (2011). The Impact of Induction and Mentoring Programs for Beginning Teachers: A Critical Review of the Research. Review of Educational Research, 81(2), 201-233.

Johari, K., Ismail, Z., Osman, S., \& Othman, A. T. (2009). Pengaruh Jenis Latihan Guru dan Pengalaman Mengajar Terhadap Efikasi Guru Sekolah Menengah. Jurnal Pendidikan Malaysia, 34(2), 3-14.

Krejcie, R. V., \& Morgan, D. W. (1970). Determining Sample Size for Research Activities. University of Minnesota: Duluth.

Lorin, W. A., David, R. K., \& Benjamin, S. B. (2001). A Taxonomy For Learning, Teaching And Assessing: A Revision Of Bloom's Taxonomy Educational. United states: Longman Publication.

Louis, C., Lawrence, M., \& Keith, M. (2011). Research Methods in Education (7th ed.). United Kingdom: Routledge, Taylor \& Francis.

Mahajan, S. (1999). Principles of Growth and Processing. University of Mechigan: McGraw-Hill.

Malaysia Examination Board (2013, January). Maklumat Pentaksiran Berasaskan Sekolah. Retreived August 16, 2013, from http://www.moe.gov.my/lp/index.php/component/content/article/53/216-pentaksiran-berasaska n-sekolah

Ministry of Education (2011). Analisa Keputusan SPM 2011 Sekolah Menengah Teknik dan Vokasional. Retreived November 17, 2012， from http://www.bptv.edu.my/web/dmdocuments/Analisis\%20 Peperiksaan\%20SPM\%202011\%20Peringkat\%20BPTV.pdf

Ministry of Education (2014, February). Statistik Guru Di Malaysia. Kuala Lumpur: KementerianPelajaran Malaysia.

Ministry of Education. (2009). Modul Pentaksiran Berasaskan Sekolah (MPBS). Mata pelajaran Aliran Vokasional. Kuala Lumpur: Lembaga Peperiksaan Kementerian Pelajaran Malaysia.

O'Connor, E., Fish, M., \& Yasik, A. (2004). Influence Of teacher Experince on the Elementary Classroom System. Journal of Classroom Interaction, 39(1), 10-16.

Pinsent, A. (2008). The Principles of Teaching-Method with Special Reference to Secondary Education (3rd ed.). University of California: Harrap Publisher.

Robert, L. L. (2008). Assessment and Accountability - Student Assessment and Testing (Vol. 4). London: Sage 
Publication Ltd.

Szpiczka, N. A. (1990). Display of Self (Ph.D Thesis). Syracuse University New York.

Tabachnick, B. G., \& Fidell, L. S. (1996). Using Multivariate Statistic. New York: Harper and Row.

Tan, A. M. (2010). Pentaksiran Berasaskan Sekolah (PBS) Di Malaysia-Kesediaan Guru, Isu, dan Panduan Pelaksanaan. Universiti Kebangsaan Malaysia: Gerak Budaya Enterprise.

Teresa J. F. (1999). Teacher Computer Access, Student Computer Access, Years of Teaching Experience, And Professional Development as Predictors of Competency of K-4 Ohio Public School Students on the National Educational Technology Standards (PhD. Thesis). Ohio University.

\section{Copyrights}

Copyright for this article is retained by the author(s), with first publication rights granted to the journal.

This is an open-access article distributed under the terms and conditions of the Creative Commons Attribution license (http://creativecommons.org/licenses/by/3.0/). 